\title{
Slik kan helsesøstre hjelpe foreldre til bedre samspill med barnet
}

Forskning viser at gode innfallsvinkler ved samspillsveiledning er spedbarnsrettet tale, sensitivitet, respons og gjensidig tilpasning i samspillet.

\section{Forfattere}

\section{Linn Limbodal}

Helsesøster

Eidsvoll helsestasjon

\section{Ragnhild Lunner}

Helsesøster. Kardiologisk sykepleier

Nittedal helsestasjon

\section{Anja Sigrid Larsen}

Helsesøster

Arendal helsestasjon

\section{Lisbeth Valla}

Helsesøster og førsteamanuensis

Institutt for sykepleie og helsefremmende arbeid, Oslomet

\section{Nøkkelord}

Barn Helsekontroll Helsestasjon

Sykepleien 2018 106(70336)(e-70336)

DOI: https://doi.org/10.4220/Sykepleiens.2018.70336 
Samspillet mellom foreldre og spedbarn har avgjørende betydning for barnets psykososiale utvikling. Foreldrenes evne til å være sensitive og responsive til barnets signaler, bruke spedbarnsrettet tale og være gjensidig tilpasset hverandre er sentrale elementer i samspillet som fremmer psykososial utvikling. Helses $\emptyset$ stre kan bidra til å fremme barns psykososiale utvikling gjennom samspillsveiledning.

Barn utvikles i samspill med sine omgivelser. Spesielt viktig for barnets utvikling er samspillet i de nære relasjoner, altså mor og far. Et godt samspill mellom foreldre og spedbarn har avgjørende betydning for barnets psykososiale utvikling (1).

Ifølge nasjonale faglige retningslinjer for det helsefremmende og forebyggende arbeidet $\mathrm{i}$ helsestasjonen er et av målene å bidra til et godt samspill mellom foreldre og barn. Det anbefales derfor at helsesøster veileder foreldre om samspill $\mathrm{i}$ alle helsestasjonskonsultasjoner i helsestasjonsprogrammet (1).

Samtidig som det anbefales samspillsveiledning, står det ikke hvordan dette skal gjennomføres i praksis, noe som betyr at det er stor variasjon i både gjennomføring av veiledning og kunnskapstilførselen til foreldrene.

Det er tidligere funnet at helsesøster er mer opptatt av mor enn av barnet når samspill vurderes i helsestasjonskontroller, selv om fokus bør være på både foreldrene og barnet (2).

Det trengs mer kunnskap og en tydeligere beskrivelse av hva som fremmer et godt samspill. Forskning tyder på at foreldres bruk av spedbarnsrettet tale, sensitivitet og respons og en gjensidig tilpasning kan fremme barnets psykososiale utvikling $(3,4,5,6)$.

\section{SPEDBARNSRETTET TALE}

Spedbarnsrettet tale kjennetegnes ved at den voksne bruker spesifikke lyder og sammensetning av ord i språket når man snakker til barn. Denne taleformen skiller seg fra «den vanlige eller naturlige voksentalen» ved varighet og hastighet, hvor ord og uttrykk er kortere (13). 


\section{Hva er samspill?}

Samspill er en toveis dialog med overføring av informasjon, samhørighet og gjensidig regulering av atferd $(7,8,9)$. I et samspill er det en veksling mellom invitasjon til oppmerksomhet og respons på invitasjon, hvor foreldrene ivaretar barnets behov for emosjonsregulering [ES1] [LEL2] og støtter barnet i utforskning og lek.

\section{EMOSJONSREGULERING}

Regulering av emosjoner omfatter evnen til å regulere intensiteten på den emosjonelle opplevelsen og kontrollere handlingsimpulser som følger av den.

Kilde: Tetzchner, S. V. (2012). Utviklingspsykologi. (2. utg) Oslo: Gyldendal Akademisk.

Barn er født som sosiale og kommuniserende vesener som er biologisk justert til å skape kontakt med betydningsfulle voksne. Spedbarnet viser tidlig evne til å oppfatte og bearbeide signaler, og er i stand til å kommunisere med foreldrene allerede timer etter fødsel (10). For å bli kjent med omgivelsene bruker det nyfødte barnet alle sanser (syn, hørsel, lukt, smak og berøring) og kan tidlig tone seg inn på den voksnes stemning. I dialogen med nære omsorgsgivere deltar barnet med lyder, gester og følelsesuttrykk, og barnets signaler som gråt og smil fungerer som oppmerksomhetsvekker for den voksne (10). 
Det meste av kommunikasjonen i den første tiden blir basert på ansikt-til-ansikt-interaksjoner, hvor de nære voksne evner å lese barnets følelsestilstand. Når den nære omsorgsgiveren fortolker barnets uttrykk, handlinger og følelser, løftes barnets bidrag inn i samspillet. Ved systematiske og konsekvente svar fra den voksne på barnets signaler, utvikles en emosjonell trygghet og forventninger hos barnet på hva som vil skje i samspillet. Etter hvert som barnet utvikles, endres også samspillsferdighetene. Barnet vil etter hvert bli i stand til å rette oppmerksomheten mot både person og objekt ved å la blikket og oppmerksomhet veksle mellom dem («Joint attention») $(11,12$.)

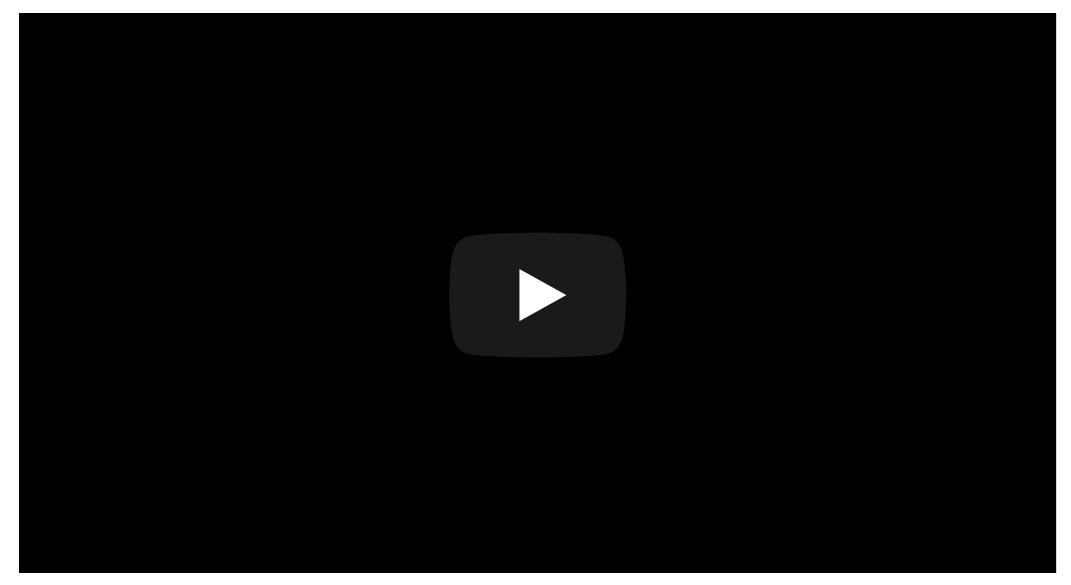

Universitetslektor Svanaug Lunde ved Læringsmiljøsenteret (UiS) bruker hånden som modell for å forklare emosjonsutvikling og emosjonsregulering. Modellen har blitt introdusert av Dr. Daniel J. Siegel. Kilde:Løringsmiljøsenteret UIS.

\section{Spedbarnsrettet tale}

En oversiktsartikkel som inkluderer 144 studier antyder at spedbarnsrettet tale (infant directed speech) har betydning for barns psykososiale utvikling (5). Spedbarnsrettet tale kjennetegnes ved at den voksne bruker spesifikke lyder (prosodiske), gjerne høyt toneleie og sammensetning av ord (leksikalske, syntaktiske) i kommunikasjonen med barnet (13). Denne taleformen skiller seg fra «den vanlige eller naturlige voksentalen» (Adult directed speech) ved varighet og hastighet, hvor ord og uttrykk er kortere. En overdriver gjerne emosjonelle ansiktsuttrykk og bruker blikket. Den voksne intoner seg i forhold til barnet og barnets rytme i språket følges $(14,5)$. 


\section{三 «En overdriver gjerne emosjonelle ansiktsuttrykk og bruker blikket.»}

Når voksne bruker spedbarnsrettet tale i samspillet vil det øke fokus i dialogen og tiltrekke spedbarnets oppmerksomhet $(15,16)$. Økt oppmerksomhet og mer aktiv deltakelse i samspillet vil kunne gi spedbarnet mer sosial erfaring og mulig fremme både læring, følelsesmessig- og kognitiv utvikling (5). Selv om denne taleformen er en intuitiv foreldrekompetanse, vil det være stor variasjon blant foreldre.

Helsesøster bør derfor legge vekt på å bevisstgjøre foreldre og fremme spedbarnsrettet tale i kommunikasjonen som foreldrene har med barnet. Dette kan gjøres ved å gjøre foreldre oppmerksom på situasjoner der de snakker på denne måten og framheve respons og betydning for barnet. Det er grunn til å tro at når foreldre blir oppmerksomme på denne talemåten, vil det motivere dem til å fortsette.

\section{Sensitivitet og respons}

Forskning tyder også på at sensitiv og responsiv omsorg vil kunne fremme barnets psykososiale utvikling (3,4, 5, 6). Begrepet sensitivitet omhandler omsorgsgivers grad av å ha korrekt oppfattelse av barnets signaler, og gi passende og konsekvente responser til barnets behov (17). Sensitivitet kan derfor synes å innebære i hvilken grad omsorgsgiver tolker barnet på riktig måte, altså ikke tolker barnets signaler ut ifra egne behov og ønsker, og samtidig reagerer på en måte som vil gi barnet en opplevelse av at omsorgsgiver er tilgjengelig for barnets behov. For å få dette til er det viktig at foreldrene blir bevisstgjort på å se spedbarnet som en aktiv kommunikasjonspartner (18). 
Helsesøster kan fremme foreldresensitivitet ved å observere og utforske barnet sammen med foreldrene.

De kan sammen observere og reflektere over barnets kapasitet, ressurser og behov for utviklingsstøtte. Hvilke signaler gir barnet? Er barnet urolig, trøtt, våken eller oppmerksomt? Når helsesøster hjelper foreldrene å tolke barnets signaler, vil det kunne bidra til å sensitivisere foreldrene. På lengre sikt kan det hjelpe barnet til å regulere seg selv (19).

\section{三 «Helsesøster kan fremme foreldresensitivitet ved å observere og utforske barnet sammen med foreldrene.»}

Enkelte daglige situasjoner, som for eksempel

bleieskift, kan bli automatisert. Situasjonen helsesøster observerer på helsestasjonen reflekterer derfor ikke nødvendigvis samspillskvaliteten mellom foreldre og barn (4). Helsesøster bør av den grunn observere flere ulike samspillssituasjoner, samt legge til rette for at foreldre kan få anledning til å fortelle om deres samspillsopplevelser. Et slikt arbeid er i tråd med våre Nasjonale faglige retningslinjer, som sier at helsesøster gjennom samspillsveiledning bør bidra til å fremme et godt nok samspill, samtidig som hun skal korrigere uønsket eller dårlig samspill (1).

\section{Gjensidig tilpasning}

En gjensidig tilpasning i samspillet kan ha betydning for barns psykososiale utvikling (5, 20). Gjensidig tilpasning (co-regulation) er en sosial prosess, hvor foreldre og barn på en dynamisk måte tilpasser sine handlinger i overensstemmelse med de pågående og forventete handlingene til den andre (21). Som en konsekvens av den gjensidig regulerte interaksjonen blir en felles sosial ramme og forståelse skapt og bidrar til en kompetanseoverføring begge veier. 
Gjensidig tilpasning i samspillet skapes i helt vanlige omsorgsaktiviteter. For å bidra til å øke en gjensidig tilpasning i samspillet kan helsesøster tydeliggjøre hvordan foreldre og barn tolker hverandres bevegelser og ytringer. Foreldrenes respons kan øke barnets initiativ og bedre samarbeidet (6).

Ofte blir samspill dokumentert i barnets journal uten at observasjoner uttrykkes og deles. Å sette ord på samspillsobservasjoner er en måte helsesøster kan bevisstgjøre foreldre. Helsesøster bør fortelle foreldre hva som er bra i deres samspill med barnet og på den måten oppmuntre dem til å gjøre mer av dette. Hun kan også demonstrere et godt samspill, for eksempel når hun undersøker barnet. Ved dokumentasjon bør helsesøster konkret beskrive de observasjoner av samspillet hun gjør, ikke kun skrive «godt samspill».

\section{Oppsummering}

Retningslinjene for helsestasjonen anbefaler samspillsveiledning på alle konsultasjoner i helsestasjonsprogrammet, men de beskriver ikke hvordan dette skal gjøres. Helsesøster kan fremme spedbarns psykososiale utvikling gjennom samspillsveiledning.

Forskning viser at spedbarnsrettet tale, sensitivitet, respons og gjensidig tilpasning i samspillet er elementer som er spesielt viktige for å fremme barns psykososiale utvikling. Helsesøster bør integrere denne kunnskapen i veiledningen til foreldre som en naturlig del av konsultasjonene. Dette kan gjøres gjennom felles refleksjon over samspillet med barnet, informasjon, demonstrasjon og ved at helsesøster beskriver hva hun har observert under konsultasjonen.

\section{Referanser}


1. Helsedirektoratet. Nasjonal faglig retningslinje for det helsefremmende og forebyggende arbeidet $\mathrm{i}$ helsestasjon, skolehelsetjeneste og helsestasjon for ungdom. Oslo: Helsedirektoratet; 2017. Tilgjengelig fra:

https://helsedirektoratet.no/retningslinjer/helsestasjonsog-skolehelsetjenesten (nedlastet 17.09.17)

2. Appleton JV, Harris M, Oates J, Kelly C. Evaluating health visitor assessments of mother-infant interactions: a mixed methods study. Int J nurs Stud. 2013:50(1):5-15.

3. Narvaez D, Gleason T, Wang L, Brooks J, Lefever JB, Cheng Y. The evolved development niche: Longitudinal effects of caregiving practices on early childhood psychosocial development. Early childhood research quarterly. 2013;28(4):759-73.

4. Maas AJBM, Vreeswijk CMJM, van Bakel HJA. Effect of situation on Mother- infant interaction. Infant Behavior and Development. 2013;36(1):42-9. DOI: 10.1016/j.infbeh.2012.10.006

5. Saint-Georges C, Chetouani M, Cassel R, Apicella F, Mahdhaoui A, Muratori F, Laznic M, Cohen D. Motherese in interaction: at the cross-road of emotion and cognition? PloS one. 2013 november;8(10)e78103. DOI: 10.1371/journal.pone.0078103

6. Nugent JK, Bartlett JD, Von Ende A, Valim C. The effects of the newborn behavioral observations (NBO). System on sensitivity in mother-infant interactions. Infants and Young Children. 2017;30(4):257-68. DOI: 10.1097/IYC.0000000000000103

7. Smith L, Ulvund SE. Spedbarnsalderen. Oslo: Gyldendal Norsk Forlag; 2004. 
8. Sameroff AJ, Chandler MJ. Reproductive risk and the continuum of caretaking casualty. In Horowitz FD, Hetherington EM, Scarr-Salapatek S, Siegel GM.

Review of child development research. Chicago IL: University of Chicago Press.1975;4:187-244.

9. Sameroff AJ. The transactional model of development: how children and contexts shape each other. Washington DC: American Psychological Association; 2009.

10. Trevarthen C. The intersubjective psychobiology of human meaning: learning of culture depends on interest for co-operative practical work-and affection for the joyful art of Good Company. Psychoanalytic Dialogues. 2009;19(5):507-18.

Doi:10.1080/10481880903231894

11. Bruner J. From joint attention to the meeting of minds. I: Moore C, Dunham P, red. Joint attention: Its origins and role in development. Hillsdale NJ:

Erlbaum: 1995. s. 1-14.

12. Tomasello M. Origins of human communication. Cambridge MA: MIT Press; 2008.

13. Soderstrom M. Beyond babytalk: Re-evaluating the nature and content of speech input to preverbal infants. Developmental Review, 2007;27(4):501-32.

14.Braarud HC. Samspill mellom to måneder gamle spedbarn og omsorgsgiver. I: Moe V, Slinning K, Hansen ME, red. Håndbok i sped- og småbarns psykiske helse. Oslo: Gyldendal Akademisk; 2010. s.137-56.

15. Golinkoff RM, Can DD, Soderstrom M, HirshPasek K. (Baby)Talk to me: The social context of infant-directed speech and its effects on early language acquisition. Current Directions in Psychological Science. 2015;24(5):339-44. 
16. Butler SC, O’Sullivan LP, Shah BL, Berthier NE. Preference for infant-directed speech in preterm infants. Infant Behavior and Development. 2014 november;37(4):505-11.

17. Ainsworth MDS, Blehar MC, Waters E, Wall S. Patterns of attachment: A psychological study of the strange situation. Hillsdale NJ: Eribaum; 1978

18. Stern DN. Spedbarnets interpersonlige verden. Oslo: Gyldendal Akademisk; 2003

19. Smith L. Tidlig utvikling, risiko og psykopatologi. I: Moe V, Slinning K, Hansen ME. red. Håndbok i sped- og småbarns psykiske helse. (s. 29-52). Oslo: Gyldendal Akademisk; 2010.

20. Killen K. Sveket 1. Risiko og omsorgssvikt - et helseproblem og tverrfaglig ansvar. Oslo:

Kommuneforlaget; 2015.

21. Fogel A. Two principles of communication: coregulation and framing. I: Nadel J, Camioni L. red. New perspectives in early communicative development. London and New York: Routledge;1993 